\title{
Overview Perkembangan Pemanfaatan Energi Primer Gas Bumi Di Indonesia
}

\author{
Aron Pangihutan Christian Tampubolon ${ }^{1}$, Berkah Fajar Tamtomo Kiono ${ }^{2}$ \\ ${ }^{1}$ Magister Energi, Sekolah Pascasarjana, Universitas Diponegoro; \\ 2Departemen Teknik Mesin, Fakultas Teknik, Universitas Diponegoro;
}

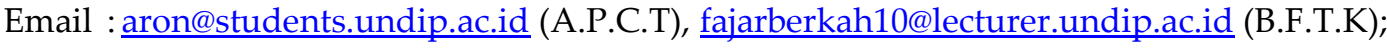

\begin{abstract}
Abstrak : Gas bumi merupakan salah satu energi primer di Indonesia yang memiliki berbagai peranan baik di sektor industri maupun rumah tangga. Gas bumi masih dipandang energi yang lebih bersih dan kompetitif bila dibandingkan dengan energi fosil lainnya namun terdapat sejumlah tantangan untuk mencapai target bauran energi primer gas bumi. Tantangan Indonesia masih memiliki cadangan gas bumi sebesar 77,29 TSCF pada tahun 2019 atau potensi cadangan berjangka waktu 29 tahun berdasarkan production to reserve ratio. Potensi cadangan ini dinilai lebih kecil bila dibandingkan dengan sumber energi fosil lainnya seperti jangka waktu cadangan batubara sampai 82 tahun. Tantangan lainnya adalah persentase ekspor gas bumi yang masih tinggi, pembangunan infrastruktur pemanfaatan gas bumi serta tingkat partisipasi dalam aktivitas eksplorasi wilayah kerja cadangan gas bumi. Tantangan ini dapat dikelola dengan dukungan kebijakan pemerintah untuk peningkatan aktivitas eksplorasi, perbaikan tata kelola dan hilirisasi gas bumi, penekanan angka ekspor gas bumi dengan persiapan pengembangan infrastruktur penyerapan suplai gas bumi untuk kebutuhan domestik, serta koordinasi dengan semua pihak terkait untuk memastikan pemenuhan perizinan terutama izin lingkungan dan isu sosial. Pengembangan produk DME sebagai substitusi impor LPG juga dapat dilakukan untuk memaksimalkan penggunaan gas bumi domestik. Pada masa pandemi Covid-19, penurunan energi primer lain seperti minyak bumi dan batubara tentunya menjadi kesempatan untuk meningkatkan persentase bauran energi gas bumi mencapai $22 \%$. Penurunan harga gas bumi selama masa pandemi yang mengakibatkan penurunan ekspor gas dapat menjadi kesempatan untuk memanfaatkan gas bumi bagi kebutuhan domestik.
\end{abstract}

Kata Kunci : Gas Bumi, Energi Primer, Bauran Energi

\section{Pendahuluan}

Gas bumi merupakan energi primer dominan ketiga setelah minyak bumi dan batubara yang mana berperan penting dalam kebijakan bauran energi di Indonesia (ESDM, 2018). Gas bumi memiliki berbagai peranan baik di sektor industri maupun rumah tangga. Pemakaian skala kecil gas bumi dapat dipakai untuk transportasi dan rumah tangga sampai pemakaian skala besar untuk industri pupuk dan ketenagalistrikkan. Penggunaan gas bumi saat ini dioptimalkan dan diatur melalui kebijakan pemerintah. Menurut Peraturan Menteri ESDM no. 06 Tahun 2016 tentang Ketentuan dan Tata Cara Penetapan Alokasi dan Pemanfaatan serta Harga Gas Bumi, alokasi dan pemanfaatan gas 
bumi berdasarkan prioritas adalah untuk transportasi, rumah tangga, dan pelanggan kecil; peningkatan produksi migas nasional; industri pupuk; industri berbasis gas bumi; penyediaan tenaga listrik; industri yang menggunakan gas bumi sebagai bahan bakar.

Gas bumi diharapkan mampu menjadi penghubung atau intermiten antara energi fosil ke energi terbarukan. Sebagai contoh gas bumi dapat berperan penting dalam industri pembangkit untuk menggantikan batubara atau penggunaan bahan bakar gas (BBG) untuk menggantikan bahan bakar minyak (BBM) pada sektor transportasi. Gas bumi masih dipandang energi yang lebih bersih dan kompetitif bila dibandingkan dengan energi fosil lainnya (ESDM, 2018) (Shell,2018). Melihat hal tersebut maka potensi pemanfaatan dan pengembangan gas bumi di Indonesia masih relevan sampai beberapa tahun ke depan.

\section{Potensi Pemanfaatan dan Rencana Pengembangan Gas Bumi}

Indonesia masih memiliki cadangan gas bumi sebesar 77,29 triliun kaki kubik (TSCF) pada tahun 2019 (ESDM, 2019). Potensi cadangan yang terlihat pada gambar 1 ini masih dapat menyediakan jangka waktu 29 tahun ketersediaan produksi berdasarkan production to reserve ratio, dengan data produksi sebesar 2,64 TSCF. Potensi cadangan ini masih belum termasuk sumber gas bumi non konvensional seperti coal bed methane atau shale gas. Namun cadangan gas pada tahun 2019 ini nilainya jauh menurun dibandingkan pada tahun 2018 yang mencapai 135,55 TSCF. Hal ini dikarenakan adanya perubahan perhitungan klasifikasi cadangan yang mana status cadangan lapangan yang tidak diusahakan menjadi unrecoverable dan contingent serta penurunan besaran cadangan karena adanya perhitungan ulang akibat pengeboran baru atau data penunjang lainnya.

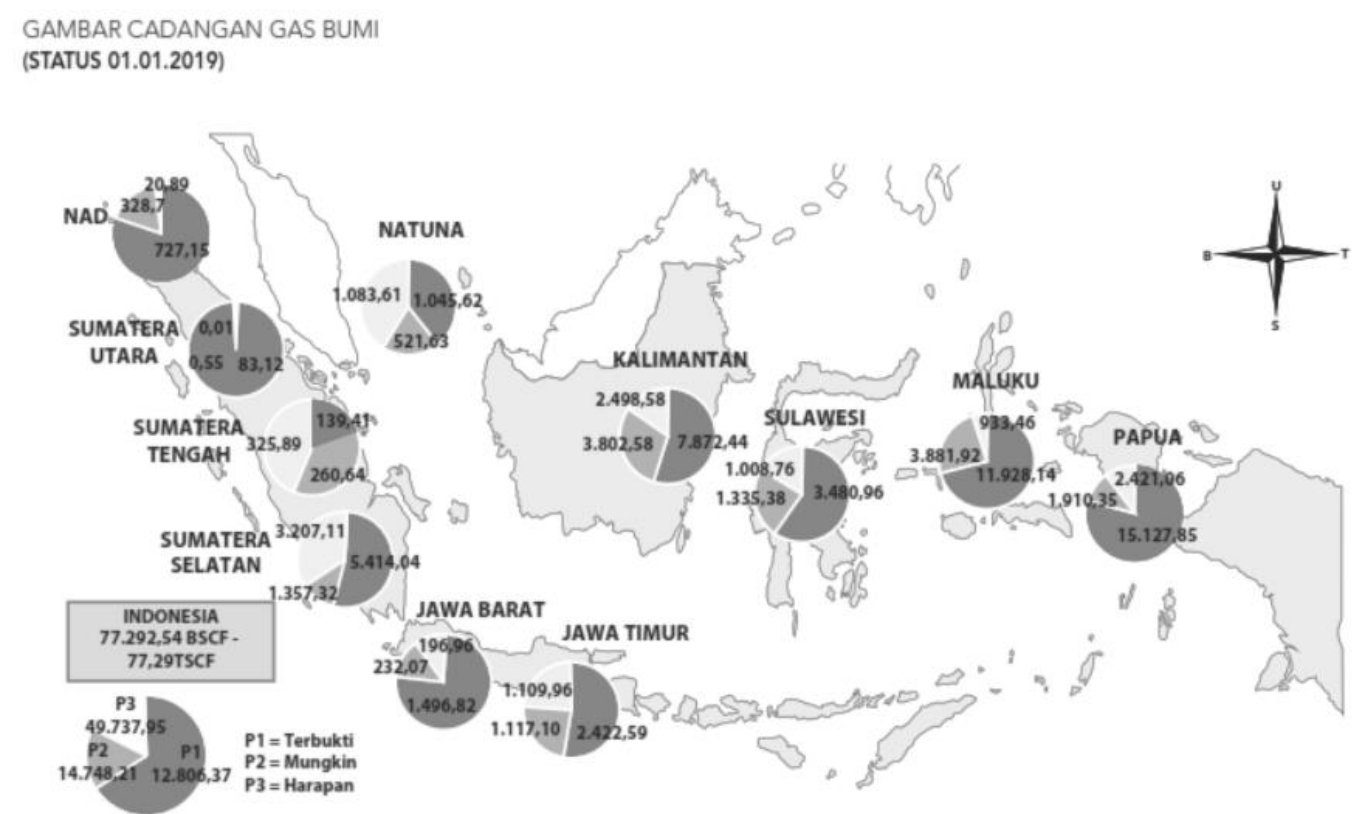

Gambar 1. Persebaran Potensi Cadangan Gas Bumi Indonesia (Sumber: ESDM, 2019)

Rantai nilai industri gas bumi dimulai dari aktivitas eksplorasi dan produksi gas bumi, yaitu aktivitas mengangkat gas bumi (lifting) dari sumber ke permukaan. Gas bumi yang ada di fasilitas produksi kemudian diproses dengan cara pemurnian, pemisahan, pencairan, dan pemampatan. Gas 
yang sudah diproses ini kemudian disalurkan melalui jaringan transmisi ke konsumen atau diubah menjadi produk yang bisa disimpan dan disalurkan melalui moda angkutan seperti LNG (liquefied natural gas), LPG (liquefied petroleum gas) dan CNG (compressed natural gas). Rantai pengusahaan gas bumi terdiri dari kegiatan usaha hulu, pengolahan, pengangkutan, penyimpanan, dan niaga. (ESDM, 2018). Terlihat pada grafik gambar 2, dari produksi tahunan gas bumi di Indonesia dimanfaatkan sebesar $64 \%$ untuk sektor dalam negeri dan sisanya adalah ekspor berupa LNG maupun jaringan pipa. Pemanfaatan untuk sektor industri mendominasi penggunaan gas bumi dalam negeri, yaitu sebesar 26,02 \%; diikuti oleh sektor kelistrikkan sebesar 13,66\%; sektor pupuk sebesar 12,1\%; LNG domestik sebesar 8,28\%; lifting sebesar 2,96\%; LPG domestik 1,68\%; BBG sebesar 0,12\%; dan jaringan gas kota sebesar 0,08\% (ESDM, 2019). Rencana yang dilakukan pemerintah untuk meningkatkan pemanfaatan gas bumi dalam negeri antara lain 4 juta sambungan gas rumah tangga pada tahun 2024; pembangunan industri petrokimia di Indonesia bagian Timur; pembangunan PLTG untuk optimalisasi LNG di Indonesia bagian Timur, jaminan kepastian pasokan gas bagi industri pupuk, petrokimia, dan industri lainnya, pembangunan pipa gas dari Sumatera hingga Jawa; dan evaluasi harga dengan pertimbangan sektor hulu sampai hilir (ESDM, 2019).

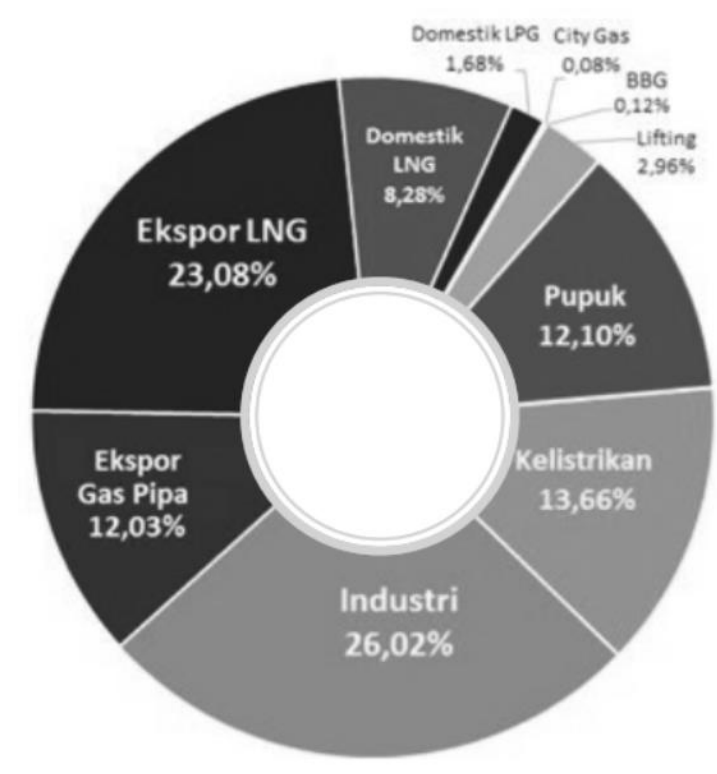

Gambar 2. Persentase Pemanfaatan Gas Bumi di Indonesia (Sumber: ESDM,2019)

\section{Kebijakan Energi Nasional untuk Gas Bumi}

Gas bumi merupakan salah satu energi primer yang menjadi pencapaian sasaran pada kebijakan energi nasional PP No. 79 Tahun 2014. Peran gas bumi pada tabel 1 dari RUEN adalah minimal 22\% pada tahun 2025 dan $24 \%$ pada tahun 2050 untuk pencapaian sasaran bauran energi yang optimal. Dari hal tersebut dapat dilihat bahwa gas bumi berbeda dengan energi fosil lainnya seperti minyak bumi dan batubara yang perannya dikurangi dalam sasaran bauran energi. Peran gas bumi sebagai energi bersih, diharapkan meningkat dari tahun ke tahun karena sebagai transisi untuk menggantikan energi fosil lainnya yang perannya dikurangi dalam bauran energi primer. Selain peran dalam bauran energi primer, pemanfaatan gas bumi berupa penggunaan gas rumah tangga juga menjadi sasaran kebijakan energi nasional. Rasio penggunaan gas rumah tangga mencapai 85\% tahun 2015. 


\section{Tabel 1}

Target Pasokan Energi Primer Gas Bumi

\begin{tabular}{clcccc}
\hline Tahun & Pasokan Energi Primer & MTOE & \multicolumn{2}{l}{ Volume Kesetaraan } & Bauran Energi Primer \\
\hline \multirow{2}{2}{2025} & GAS BUMI & 89,5 & $9.786,7$ & MMSCFD & $22,4 \%$ \\
& Gas Bumi untuk Domestik & 84,7 & $9.221,1$ & MMSCFD & \\
& Impor LPG & 4,8 & 4,0 & Juta ton & \\
GA50 & 242,9 & $27.013,1$ & MMSCFD & $24 \%$ \\
& Gas BUMI & 237,7 & $25.869,1$ & MMSCFD & \\
& Impor LPG & 5,2 & 4,4 & Juta ton & \\
\hline
\end{tabular}

Gas bumi merupakan salah satu komoditas ekspor energi di Indonesia yang mana pada tahun 2019 mencapai 36\%. Pada kebijakan energi nasional pada ketersediaan energi untuk kebutuhan nasional, ekspor energi fosil seperti gas bumi dikurang secara bertahap serta menetapkan batas waktu untuk mulai menghentikan ekspor. Hal ini untuk menunjang strategi pertama kebijakan energi nasional, yaitu mewujudkan sumber daya energi tidak dijadikan sebagai komoditas ekspor semata tetapi sebagai modal pembangunan nasional. Pemanfaatan sumber energi gas bumi diprioritaskan untuk industri, ketenagalistrikkan, rumah tangga, dan trasnportasi, diutamakan untuk pemanfaatan yang memiliki nilai tambah paling tinggi. Selain itu gas bumi termasuk dalam prioritas pengembangan energi bersama dengan energi baru dan terbarukan. Pengembangan pemanfaatan gas bumi sesuai dengan kebijakan energi nasional untuk ketenagalistrikkan, rumah tangga, transportasi, dan bahan baku industri.

Berbagai target dalam kebijakan energi nasional sangat berhubungan dengan dukungan terhadap Sustainable Development Goals (SDGs). Akses terhadap teknologi energi bersih sebesar 100\% pada tahun 2030 di indikator 7.1.2 salah satunya diturunkan ke dalam target pemanfaatan bahan bakar gas untuk memasak pada tahun 2015 sebesar 85\% (Santika et al., 2020). Selain pada kebijakan energi nasional dan rencana umum energi nasional, pemerintah menetapkan beberapa regulasi khusus untuk gas bumi. Regulasi khusus untuk pemanfaatan gas bumi di Indonesia, antara lain:

- Peraturan Presiden No. 40 Tahun 2016 tentang Penetapan Harga Gas Bumi;

- Peraturan Presiden Republik Indonesia Nomor 6 Tahun 2019 Tentang Penyediaan Dan Pendistribusian Gas Bumi Melalui Jaringan Transmisi Dan/Atau Distribusi Gas Bumi Untuk Rumah Tangga Dan Pelanggan Kecil;

- Peraturan Menteri ESDM No. 6 Tahun 2016 tentang Ketentuan dan Tata Cara Penetapan Alokasi dan Pemanfaatan serta Harga Gas Bumi;

- Peraturan Menteri ESDM No. 8 Tahun 2020 tentang Tata Cara Penetapan Pengguna dan Harga Gas Bumi Tertentu di Bidang Industri;

- Peraturan Menteri ESDM No. 10 Tahun 2020 tentang Pemanfaatan Gas Bumi untuk Pembangkit Listrik;

- Peraturan Menteri ESDM No. 25 Tahun 2017 tentang Percepatan Pemanfaatan Bahan Bakar Gas untuk Transportasi;

- Peraturan Menteri ESDM No. 32 Tahun 2017 tentang Pemanfaatan dan Harga Jual Gas Suar pada Kegiatan Usaha Hulu Migas;

- Peraturan Menteri ESDM No. 14 Tahun 2019 tentang Harga Jual Gas Bumi Melalui Pipa pada Kegiatan Usaha Hilir Migas; 
- Peraturan Menteri Energi Dan Sumber Daya Mineral Nomor 7 Tahun 2019 Tentang Pengelolaan Dan Pemanfaatan Data Minyak Dan Gas Bumi;

- Peraturan Menteri Energi Dan Sumber Daya Mineral Nomor 4 Tahun 2018 Tentang Pengusahaan Gas Bumi Pada Kegiatan Usaha Hilir Minyak Dan Gas Bumi

- Peraturan Menteri ESDM No. 52 Tahun 2018 tentang Perizinan Pada Kegiatan Usaha Minyak dan Gas Bumi;

- Peraturan Menteri ESDM No. 4 Tahun 2018 tentang Pengusahaan Gas Bumi pada Kegiatan Usaha Hilir Migas;

- Keputusan Menteri Energi Dan Sumber Daya Mineral Nomor 91 K/12/Mem/2020 Tentang Harga Gas Bumi Di Pembangkit Tenaga Listrik (Plant Gate);

- Keputusan Menteri Energi Dan Sumber Daya Mineral Nomor 89 K/10/Mem/2020 Tentang Pengguna Dan Harga Gas Bumi Tertentu Di Bidang Industri;

- Keputusan Menteri Energi Dan Sumber Daya Mineral Nomor 34 K/16/Mem/2020 Tentang Penetapan Alokasi Dan Pemanfaatan Gas Bumi Untuk Penyediaan Tenaga Listrik Oleh PT Perusahaan Listrik Negara (Persero).

\section{Kondisi Aktual Industri Gas Bumi di Indonesia}

Pembahasan dari kondisi aktual industri gas bumi dapat ditinjau dari perubahan paradigma pengelolaan energi dan pemenuhan kebijakan utama dari kebijakan energi nasional, yaitu ketersediaan energi untuk kebutuhan nasional, prioritas pengembangan energi, pemanfaatan sumber daya energi nasional, dan cadangan energi nasional.

\subsection{Perubahan Paradigma Pengelolaan Energi}

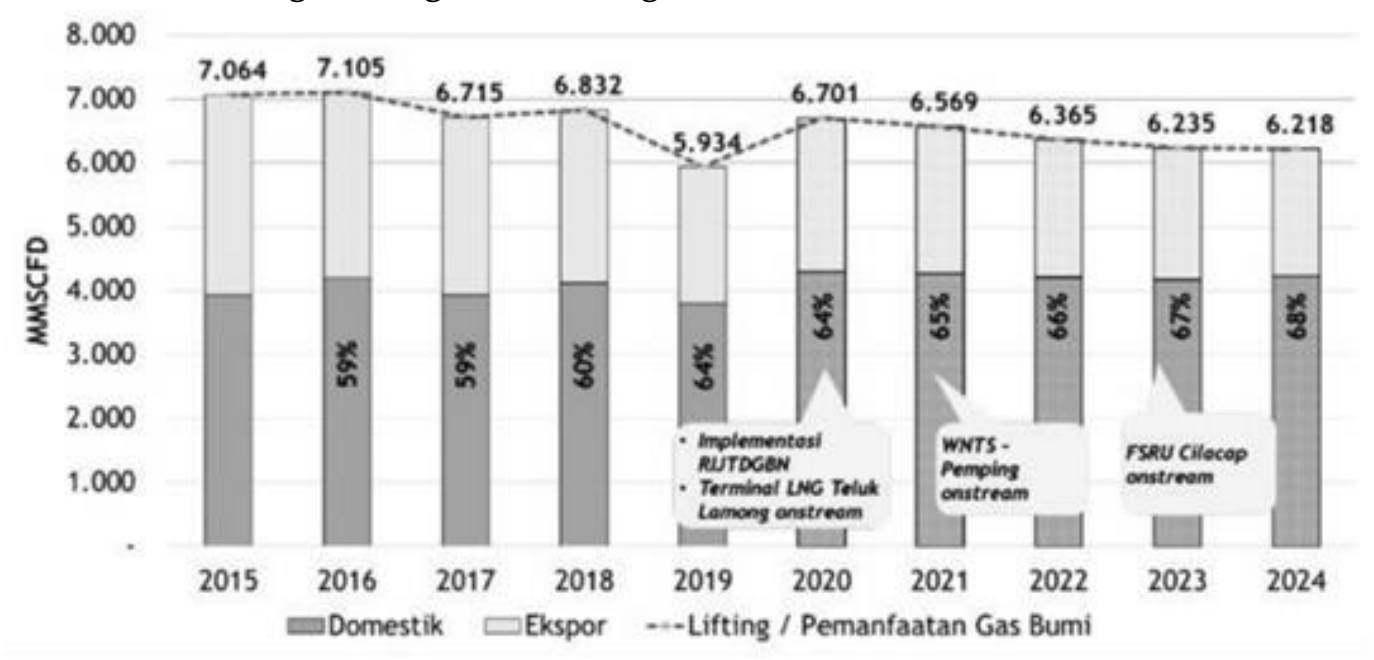

Gambar 3. Grafik Target Pemanfaatan Gas Bumi untuk Domestik (Sumber: ESDM,2019)

Berdasarkan matriks program Rencana Umum Energi Nasional (RUEN) di lampiran ke-2 PP No. 22 Tahun 2017, perubahan paradigma pengelolaan energi erat kaitannya dengan sumber daya energi tidak dijadikan komoditas ekspor melainkan sebagai modal pembangunan nasional. Pengurangan ekspor energi dan optimalisasi pemanfaatan domestik sesuai dengan wujud kemandirian energi menurut kebijakan energi nasional. Gas bumi merupakan salah satu komoditas 
ekspor sumber daya energi di Indonesia baik melalui pipa maupun LNG. Berdasarkan gambar grafik 3 dari data laporan tahunan Ditjen Migas Kementerian ESDM pada tahun 2019 menunjukkan persentase ekspor gas bumi mencapai 36\% terhadap total produksi gas bumi. Persentase ini sudah menurun jauh bila dibandingkan pada tahun 2009 yang mencapai 50\% dan 40\% pada tahun 2018 (Tim Sekretaris Jenderal Dewan Energi Nasional, 2019). Ekspor gas bumi ditargetkan selesai pada tahun 2036 sesuai dengan komitmen ekspor gas bumi.

Penurunan persentase ekspor sebesar 4\% tahun 2018-2019 sudah sangat baik walaupun persentase ekspor tahun 2019 ini masih lebih tinggi bila dibandingkan dengan proyeksi KEN pada RUEN. Persentase ekspor gas bumi pada RUEN sebesar 25,9\% dan produksi sebesar 7708 MMSCFD, yang hampir sama dengan realisasi produksi senyatanya pada tahun 2019 sebesar 7235 MMSCFD. Persentase ekspor gas bumi yang masih tinggi dikarenakan untuk pemenuhan kontrak jangka panjang sehingga tidak mudah dialihkan. Selain itu devisa dari ekspor gas bumi masih menjadi salah satu penerimaan pendapatan negara. Berdasarkan statistik keuangan dan ekonomi Indonesia oleh Bank Indonesia, nilai ekspor dari gas bumi sebesar 3510 juta USD (US Dollar) atau 3,4\% dari total nilai ekspor sampai Agustus 2020. Hal ini masih bisa ditekan mengingat bahwa nilai ekspor Indonesia sebagian besar dari sektor non-migas dan gas bumi dapat dijadikan penggerak ekonomi bagi sektorsektor industri dalam negeri. Sektor pendukung industri gas bumi berkontribusi 55,9\% PDB (Produk Domestik Bruto) Indonesia dan menyerap 61,53\% tenaga kerja Indonesia sedangkan sektor industri pengguna gas bumi berkontribusi 27,27\% PDB (Produk Domestik Bruto) Indonesia dan menyerap 19,34\% tenaga kerja Indonesia (Paramita, 2018). Gas bumi dapat menjadi salah satu sektor yang berhasil dalam perubahan paradigma pengelolaan energi karena efek ganda yang dapat diberikan terhadap pembangunan ekonomi nasional.

\subsection{Ketersediaan Energi Untuk Kebutuhan Nasional}

Berdasarkan matriks program Rencana Umum Energi Nasional (RUEN) di lampiran ke-2 PP No. 22 Tahun 2017, ketersediaan energi gas bumi untuk kebutuhan nasional dapat ditinjau dari eksplorasi sumber daya, produksi, sistem transportasi dan distribusi, keseimbangan laju produksi dan penambahan cadangan energi. Cadangan gas bumi Indonesia sebesar 77,29 triliun kaki kubik (TSCF) pada tahun 2019 (ESDM, 2019). Potensi cadangan ini masih belum termasuk sumber gas bumi nonkonvensional seperti coal bed methane atau shale gas, namun cadangan gas pada tahun 2019 ini nilainya jauh menurun dibandingkan pada tahun 2018 yang mencapai 135,55 TSCF. Hal ini dikarenakan adanya perubahan perhitungan klasifikasi cadangan yang mana status cadangan lapangan yang tidak diusahakan menjadi unrecoverable dan contingent serta penurunan besaran cadangan karena adanya perhitungan ulang akibat pengeboran baru atau data penunjang lainnya. Selain itu hasil lelang wilayah kerja (WK) migas tahun 2019 hanya mencapai 3 WK yang diminati dari 13 WK yang disiapkan, yaitu pada lapangan Selat Panjang, Anambas, dan West Ganal serta penandatanganan 3 WK migas pada lapangan Maratua, South Andaman, South Sakamang. Pencapaian hasil lelang ini masih di bawah target yang ditetapkan RUEN sebesar 9 WK per tahun yang disiapkan dan 6 WK per tahun yang dilakukan penandatanganan. 


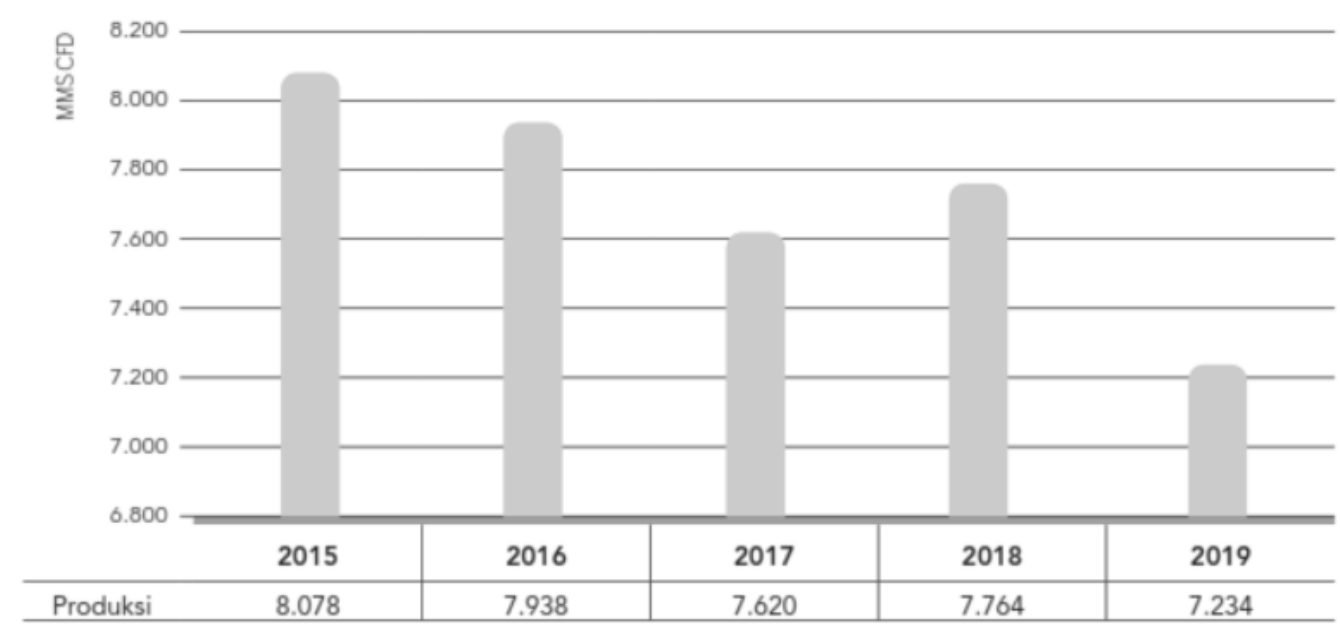

Gambar 4. Grafik Realisasi Produksi Gas Bumi Tahun 2015-2019 (Sumber: ESDM,2019)

Pada gambar grafik 4, produksi gas bumi pada tahun 2019 sebesar 7234 MMSCFD. Produksi pada tahun 2019 ini menurun apabila dibandingkan produksi pada tahun 2018 sebesar 7764 MMSCFD, namun masih mendekati proyeksi produksi lifting gas bumi pada RUEN sebesar 7708 MMSCFD pada tahun 2019. Penurunan ini dapat dikaitkan adanya penurunan produksi secara alami dari reservoir eksisting serta belum ditemukannya cadangan baru dalam jumlah yang besar. Penurunan produksi secara alami dari reservoir ini sudah diproyeksikan pada RUEN yang mana pada tahun 2025 target produksi hanya sebesar 6700 MMSCFD. Data cadangan baru yang belum ditemukan juga menjadi faktor penurunan produksi. Pada tahun 2019 cadangan terbukti gas bumi sebesar 49,74 TSCF, menurun jauh bila dibandingkan data tahun 2018 sebesar 99,06 TSCF. Penyesuaian perhitungan dan data studi cadangan gas bumi perlu disesuaikan kembali mengingat data produksi tahunan hanya sebesar 2,64 TSCF. Penyesuaian data cadangan gas bumi khususnya data cadangan terbukti digunakan untuk menghitung Reserve Replacement Ratio (RRR). Data RRR ini menunjukkan keseimbangan laju produksi tahunan dengan penambahan cadangan energi. Idealnya data produksi tahunan dan laju penemuan cadangan memiliki nilai yang sama atau RRR 100\% sesuai dengan target RUEN. Rendahnya RRR mengindikasikan minimnya kegiatan eksplorasi dan tingkat keberhasilan dari eksplorasi tersebut. Minimnya kegiatan eksplorasi ini juga berkaitan dengan hasil lelang WK migas tahun 2019 yang mana hanya mencapai 3 WK yang diminati dari 13 WK yang ditawarkan. Tingkat keberhasilan dari eksplorasi dari tahun 2019 menunjukkan bahwa dari 28 sumur eksplorasi terdapat 15 sumur yang ditemukan atau terindikasi hidrokarbon pada lapisan bor. Pemerintah sudah berupaya untuk meningkatkan partisipasi kegiatan eksplorasi migas dengan cara kebijakan permohonan izin pemanfaatan data secara online, penambahan masa eksplorasi selama 4 tahun dan diluar eksplorasi selama 10 tahun, koordinasi dengan pemerintah daerah dan instansi terkait pengadaan lahan, serta perundingan landas kontinen atau batas wilayah.

Kondisi aktual untuk pemanfaatan gas bumi di Indonesia masih terdapat memiliki beberapa tantangan atau kendala. Tantangan pertama yang dihadapi adalah infrastruktur penyaluran yang mana sumber gas bumi sangat jauh dari pengolahan maupun pusat permintaan pada konsumen (Purwanto et al., 2016). Infrastruktur gas bumi terdiri dari infrastruktur pipa dan non-pipa. Infrastruktur pipa terdiri dari pipa transmisi, pipa dedicated hilir, pipa kepentingan bersama, pipa dedicated hulu dan jaringan gas bumi untuk rumah tangga. Infrastruktur non pipa terdiri dari kilang 
LNG, FSRU/FSU, land-based regasification, fasilitas CNG, dan fasilitas LPG (ESDM, 2018). Berdasarkan data BPH Migas pada tahun 2020 panjang kumulatif pipa distribusi dan transmisi gas bumi sebesar 14855,5 km. Realisasi ini masih belum mencapai target di RUEN yang mana pada tahun 2019 target panjang pipa distribusi/transmisi gas bumi menjadi $18322 \mathrm{~km}$. Jaringan gas rumah tangga yang terbangun sampai tahun 2019 sejumlah 400.269 sambungan rumah, masih jauh dari target RUEN sebesar 4,7 juta rumah tangga pada tahun 2025. Sambungan gas rumah tangga yang harus terbangun setiap tahunnya sebesar 716.622 sambungan rumah. Target ini cukup sulit untuk direalisasikan mengingat pembangunan jaringan gas pada tahun 2019 sebesar 74496 sambungan rumah. Pembangunan jaringan gas rumah tangga ini memiliki beberapa kendala terkait kendala perizinan di pusat dan daerah, isu sosial, dan kendala teknis seperti kualifikasi penyedia jasa, peralatan kalibarasi gas meter yang masih langka, dan kualifikasi tenaga kerja lapangan, serta review dokumen teknik seperti front end engineering design dan detail engineering design construction. Koordinasi dengan pihak terkait seperti pemerintah daerah setempat, kementerian terkait, serta Pertamina dan PGN (PT Perusahaan Gas Negara Tbk) selaku pelaksana pembangunan jaringan gas sangat diperlukan untuk percepatan pembangunan jaringan gas.

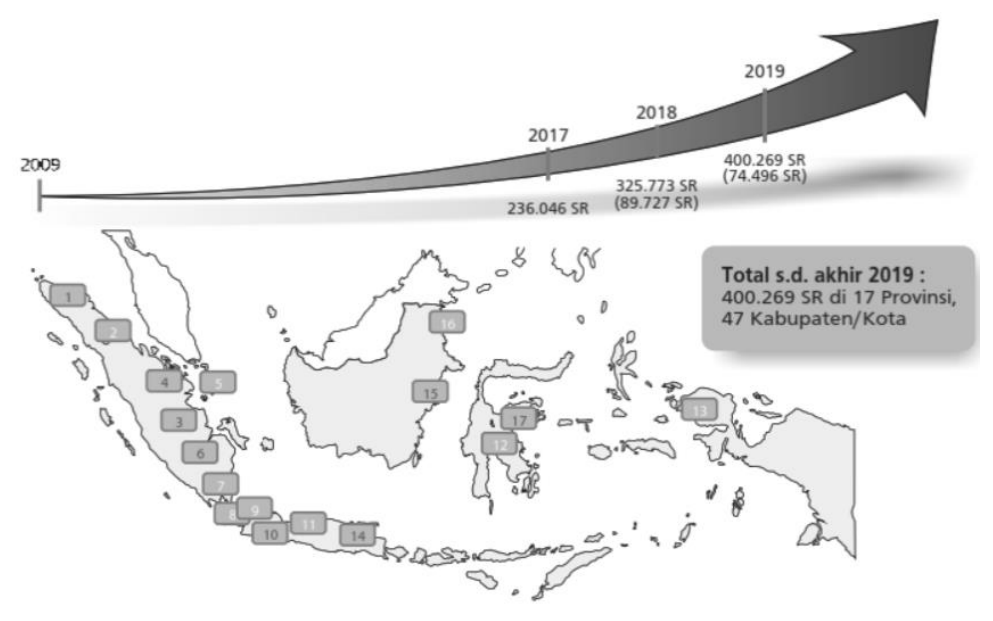

Gambar 5. Perkembangan dan Capaian Jaringan Gas melalui APBN (Sumber: ESDM,2019)

Selain itu pembangunan jaringan transmisi dan distribusi gas ini juga berkaitan dengan minimya pengembangan fasilitas usaha produksi gas bumi seperti pengolahan dan penyimpanan. Kapasitas pengolahan LNG sebagai contoh tidak mengalami peningkatan sejak tahun 2015 dikarenakan belum adanya kilang pengolahan baru, walaupun kilang baru ini sudah ditargetkan pada RUEN dengan adanya kilang LNG South Sulawesi pada tahun 2017. Perkembangan juga belum terjadi pada pengolahan LPG yang mana 9 dari 29 kilang LPG berhenti beroperasi karena tidak mendapat pasokan bahan baku gas dan izin pengolahan gas bumi tidak diperpanjang.

\subsection{Prioritas Pengembangan Energi}

Prioritas pengembangan energi pada matriks program Rencana Umum Energi Nasional (RUEN) di lampiran ke-2 PP No. 22 Tahun 2017 memuat tentang target bauran energi primer pada tahun 2025 dan 2050. Target bauran energi primer gas bumi minimal sebesar 22\% pada tahun 2025 dan $24 \%$ pada tahun 2050. Berdasarkan data bauran energi nasional 2019 oleh DEN (Dewan Energi Nasional) menyebutkan realisasi bauran energi primer gas bumi sebesar 44,09 MTOE atau 20,13\%. 
Energi primer gas bumi yang diperkirakan dapat menekan angka bauran energi minyak bumi dan batubara pada realisasinya cenderung menurun dibandingkan periode 2015-2017. Hal ini selaras dengan kinerja hulu gas bumi utamanya pada data cadangan gas bumi. RRR gas bumi pada data terakhir tahun 2017 hanya sebesar 21\%, jauh dari target RUEN sebesar 100\%. Selain itu production to reserve ratio pada tahun 2018-2019 menurun dari 33 tahun menjadi 29 tahun sehingga menandakan cadangan gas bumi yang bisa dimanfaatkan semakin menurun.

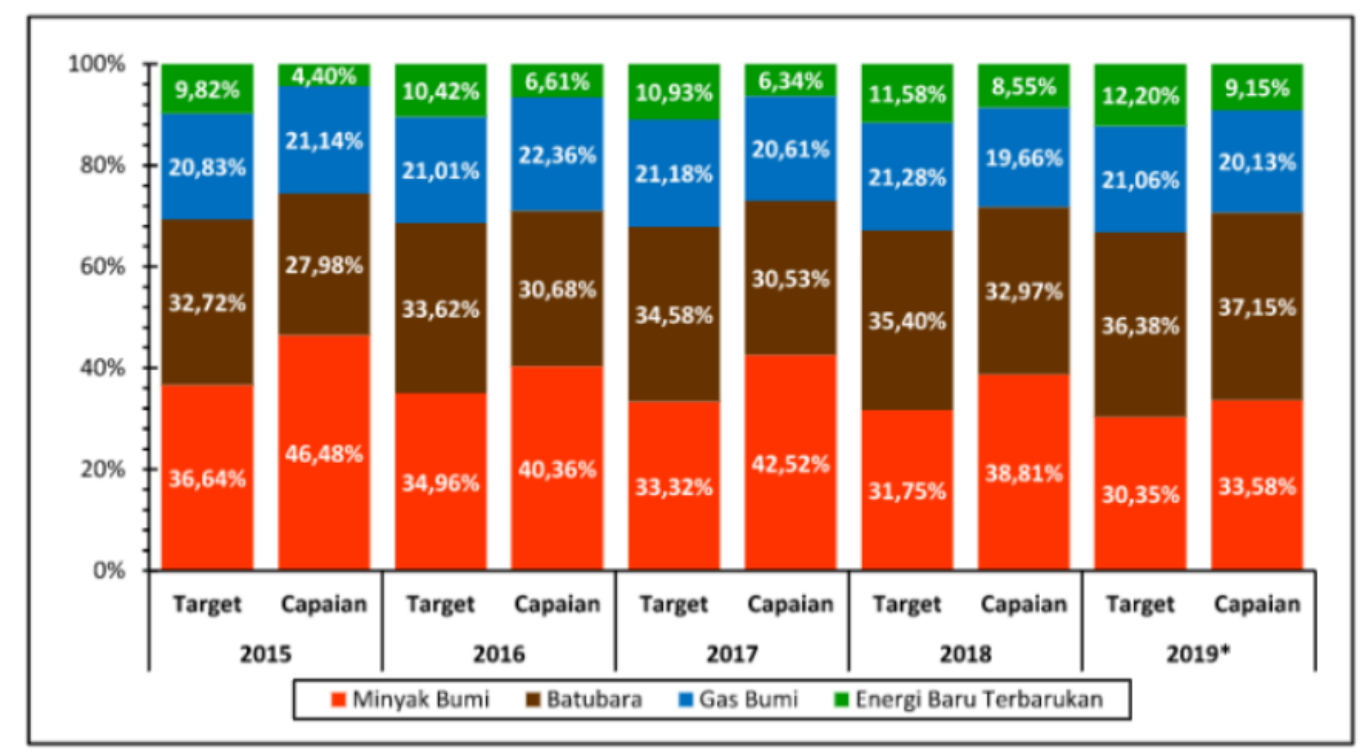

Gambar 6. Target dan Capaian Bauran Energi Primer (Sumber: DEN,2020)

\subsection{Pemanfaatan Sumber Daya Energi Nasional}

Pemanfaatan sumber energi gas berdasarkan matriks program Rencana Umum Energi Nasional (RUEN) di lampiran ke-2 PP No. 22 Tahun 2017 memuat tentang pemanfaatan sumber energi gas untuk industri ketenagalistrikkan, rumah tangga, dan transportasi, diutamakan untuk pemanfaatan yang memiliki nilai tambah tinggi. Prioritas pertama untuk pemanfaatan gas adalah untuk ketenagalistrikkan. Target kapasitas pembangkit listrik berbahan bakar gas mencapai sebesar 36 GW di tahun 2025 dan 114 GW pada tahun 2050. Berdasarkan statistik ketenagalistrikkan pada tahun 2019 menunjukkan kapasitas pembangkit tenaga listrik yang menggunakan sumber energi gas sebesar 19,86 GW. Realisasi ini tentunya masih rendah bila dibandingkan target di dalam RUEN.

Berdasarkan perbandingan energi primer dan produksi listrik berdasarkan jenis energi primer menunjukkan bahwa batubara masih mendominasi sumber energi ketanagalistrikkan lalu diikuti sumber energi gas bumi. Penggunaan batubara yang masih mendominasi karena biaya pokok penyediaan yang murah bila dibandingkan sumber energi primer lainnya dan batubara masih menjadi andalan untuk wilayah terdepan, tertinggal, dan terluar (3T). Hal ini tentunya penggunaan gas bumi harus didorong untuk transisi penggunaan energi fosil ke energi terbarukan sesuai dengan target bauran energi primer. Akselerasi pembangunan infrastruktur pemanfaatan gas bumi diperlukan untuk meningkatkan target bauran energi primer dengan menunjang daerah-daerah yang belum mendapat pasokan gas bumi. Pemanfaatan gas bumi akan disesuaikan dengan nilai tambah pada masing-masing daerah. 


\section{Tabel 2.}

Perbandingan Energi Primer dan Produksi Listrik Berdasarkan Jenis Energi Primer pada Tahun 2015 - 2019 (Sumber: DEN,2020)

\begin{tabular}{|c|c|c|c|c|c|c|c|c|c|c|}
\hline \multirow{3}{*}{$\begin{array}{l}\text { Jenis } \\
\text { Energi }\end{array}$} & \multicolumn{2}{|c|}{2015} & \multicolumn{2}{|c|}{2016} & \multicolumn{2}{|c|}{2017} & \multicolumn{2}{|c|}{2018} & \multicolumn{2}{|c|}{2019} \\
\hline & $\begin{array}{l}\text { Energi } \\
\text { Primer }\end{array}$ & $\begin{array}{c}\text { Produksi } \\
\text { Energi } \\
\text { Listrik }\end{array}$ & $\begin{array}{l}\text { Energi } \\
\text { Primer }\end{array}$ & $\begin{array}{c}\text { Produksi } \\
\text { Energi } \\
\text { Listrik }\end{array}$ & $\begin{array}{l}\text { Energi } \\
\text { Primer }\end{array}$ & $\begin{array}{c}\text { Produksi } \\
\text { Energi } \\
\text { Listrik }\end{array}$ & $\begin{array}{l}\text { Energi } \\
\text { Primer }\end{array}$ & $\begin{array}{c}\text { Produksi } \\
\text { Energi } \\
\text { Listrik }\end{array}$ & $\begin{array}{l}\text { Energi } \\
\text { Primer }\end{array}$ & $\begin{array}{c}\text { Produksi } \\
\text { Energi } \\
\text { Listrik }\end{array}$ \\
\hline & MTOE & TWh & MTOE & TWh & MTOE & TWh & MTOE & TWh & MTOE & TWh \\
\hline EBT & 8,12 & 30,73 & 9,65 & 36,45 & 9,7 & 36,88 & 13,56 & 48,07 & 13,59 & 48,05 \\
\hline $\begin{array}{c}\text { Minyak } \\
\text { Bumi }\end{array}$ & 8,81 & 33,83 & 4,88 & 18,74 & 4,53 & 21,42 & 4,75 & 18,22 & 3,3 & 12,68 \\
\hline Gas Bumi & 10,78 & 54,12 & 13,44 & 65,78 & 15,2 & 48,21 & 15,1 & 61,47 & 15,01 & 61,09 \\
\hline Batubara & 37,79 & 145,05 & 41,07 & 157,62 & 40,77 & 172,68 & 43,93 & 168,63 & 46,48 & 183,03 \\
\hline Total & 65,5 & 263,73 & 69,04 & 278,59 & 70,2 & 279,19 & 77,34 & 296,38 & 78,38 & 304,84 \\
\hline
\end{tabular}

Prioritas kedua pasokan gas bumi dimanfaatkan sebagai bahan baku industri strategis yang memiliki nilai tambah tinggi bagi perekonomian nasional. Salah satu yang menjadi prioritas adalah pembangunan kawasan industri dan petrokimia hulu berbahan baku gas untuk menyerap produksi gas dalam negeri. Pada dokumen Rencana Pembangunan Jangka Menengah Nasional 2020-2024 terdapat 4 lapangan gas bumi, yaitu Jambaran Tiung Biru, Abadi, Asap Kido-Merah, dan Tangguh Train-3 yang akan dibangun pada periode 2020-2024. Pemanfaatan dari lapangan gas bumi tersebut direncanakan untuk kelistrikkan, petrokimia, dan industri. Selain itu terdapat kawasan industri Teluk Bintuni yang menjadi prioritas RUEN untuk pemanfaatan gas bumi. Kawasan industri Teluk Bintuni direncanakan sebagai kawasan petrokimia hulu untuk menyerap gas bumi dari lapangan Tangguh.

Prioritas ketiga pemanfaatan gas bumi untuk kebutuhan domestik rumah tangga. Pemanfaatan gas bumi untuk kebutuhan domestik rumah tangga yang paling banyak adalah pemakaian LPG untuk bahan bakar memasak. Pemakaian LPG untuk memasak merupakan salah satu program akses energi modern di rumah tangga selain energi listrik. Program substitusi kerosin menjadi LPG untuk kebutuhan memasak menjadi program pemerintah yang berhasil meningkatkan persentase penggunaan LPG rumah tangga sebesar 89\% pada tahun 2018 (Hartono et al., 2020). Realisasi penjualan LPG subsidi pada tahun 2019 sebesar 6,84 juta MT dengan biaya subsidi rata-rata subsidi Rp.5536,85/kg atau total sebesar Rp 42,46 trilliun (ESDM,2019). Biaya subsidi ini tentunya bisa ditekan salah satunya dengan penggunaan jaringan gas rumah. Penggunaan jaringan gas menggantikan LPG dapat memberikan penghematan sebesar Rp 878,- (LPG 3 kg); Rp 71227,- (LPG 5,5 kg); Rp 76913 (LPG $12 \mathrm{~kg}$ ) (Andriawan et al., 2020). Jaringan gas bumi untuk rumah tangga akan menjadi infrastruktur unggulan karena memberikan penghematan bila dibandingkan dengan tabung LPG rumah tangga, efisiensi pembakaran lebih tinggi, emisi jauh lebih bersih dibanding BBM dan kayu bakar, memiliki tekanan yang lebih kecil sehingga meminimalkan ledakan gas di rumah tangga, dan tersedia setiap saat (ESDM,2019) (Triyatno, 2018).

Prioritas selanjutnya adalah pemanfaatan gas bumi untuk sektor transportasi. Berdasarkan Neraca Gas Indonesia 2018-2027 menunjukkan bahwa penggunaan gas bumi untuk transportasi sebesar 61,59 MMSCFD pada 2018 dan 95,55 MMSCFD pada 2027. Penggunaan gas bumi untuk transportasi akan mengalami peningkatan karena dinilai memberikan dampak lingkungan yang lebih 
Vol. 2, No. 1, pp $36-52$

doi: $10.14710 /$ jebt.2021.10049

minim dibandingkan bahan bakar minyak. Pengurangan emisi yang spesifik untuk kendaraan bahan bakar gas (BBG) bila dibandingkan dengan bensin sebesar 60-80 \% CO (Karbonmonoksida), 50-80\% NOx (Nitrogen Oksida), dan 20\% $\mathrm{CO}_{2}$ (ENGVA, 2002).

\section{Gas Bumi dan Pandemi Covid-19}
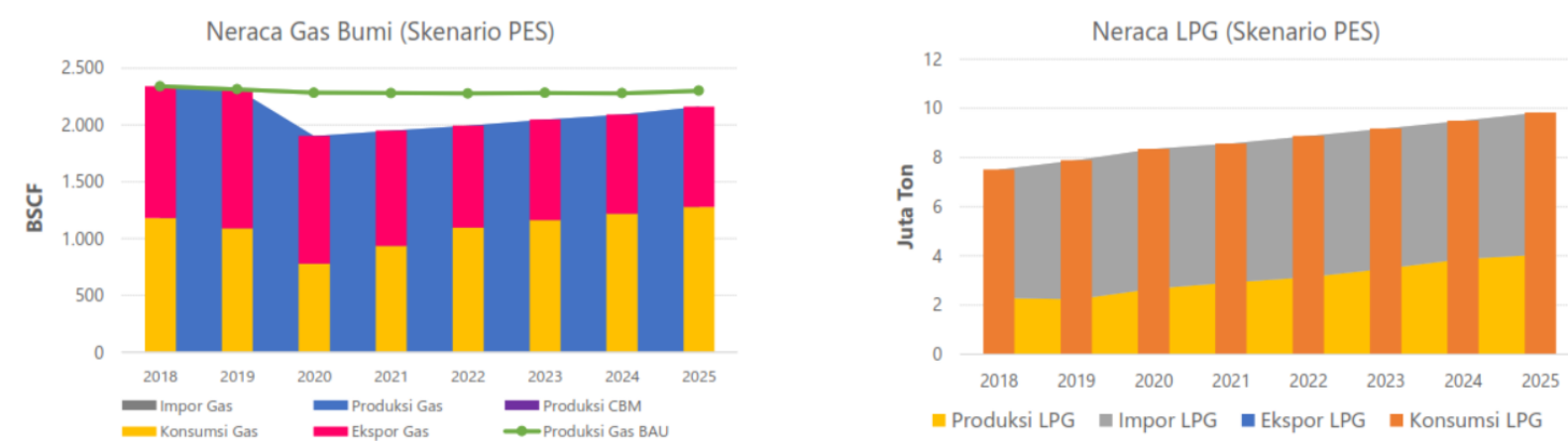

Gambar 7. Proyeksi Neraca Gas Bumi dan LPG setelah Pandemi Covid-19 (BPPT,2020)

Pemakaian energi gas bumi di sektor industri selama masa pandemi covid-19 mengalami penurunan. Penurunan ini terjadi karena permintaan dari sektor industri domestik serta ekspor gas bumi yang sampai 127 BSCF - 380 BSCF. Hal ini tentunya berbeda dengan neraca penyediaan LPG yang mengalami peningkatan untuk kebutuhan rumah tangga sebesar 170 ribu ton LPG atau 3\% akibat kebijakan bekerja dari rumah (BPPT,2020). Secara global terjadi penurunan permintaan gas bumi secara global pada tahun 2020 sebesar $2 \%$.

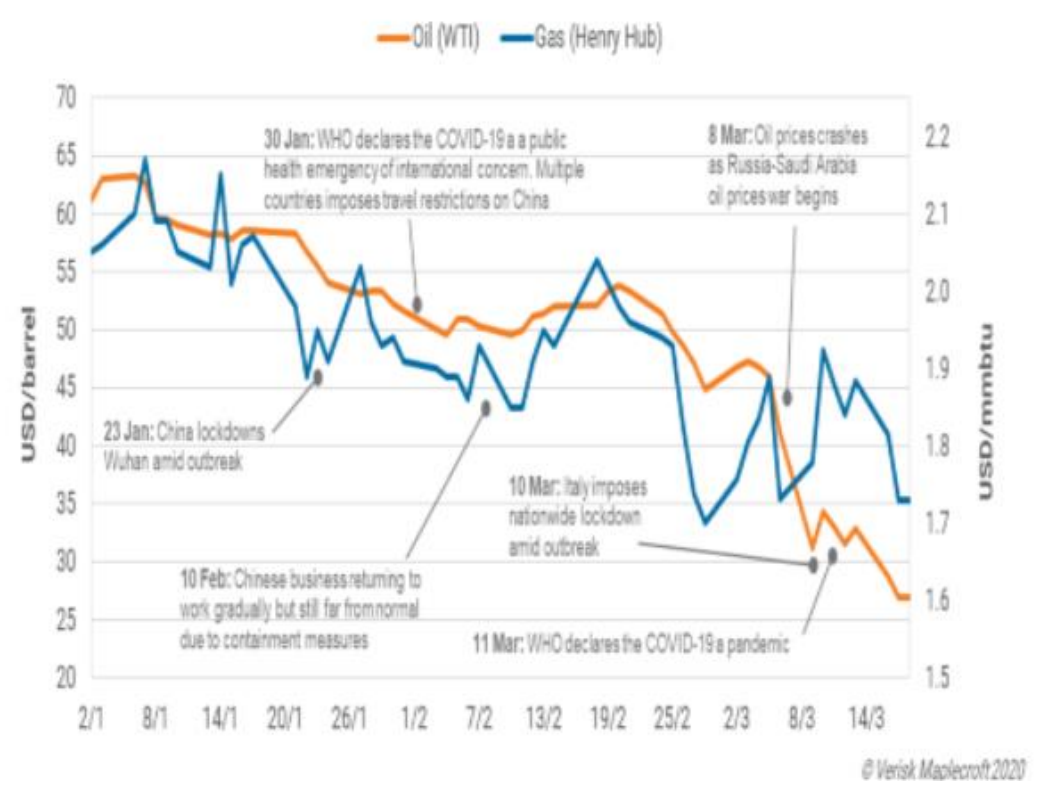

Gambar 8. Perkembangan Harga Gas Bumi Sebelum dan Sesudah Pandemi Covid-19(Widyastuti \&

Nugroho, 2020)

Penyediaan gas bumi tidak mengalami banyak penurunan akibat pandemi Covid-19 karena didukung oleh kenaikan LPG rumah tangga. Pengaruh dari masa pandemi terhadap industri gas bumi banyak kepada penyesuaian harga. Industri gas bumi biasanya beriringan dengan industri 
minyak bumi sehingga fluktuasi harga gas bumi mengikuti harga minyak. Berdasarkan grafik gambar 4, harga gas bumi sebelum pandemi berkisar di atas 2 USD/MMBTU namun menurun setelah masa pandemi di bawah 2 USD/MMBTU. Penurunan harga ini disebabkan menurunnya permintaan pada minyak dan gas bumi. Hal ini turut mempengaruhi penurunan ekspor gas bumi karena harga yang tidak menguntungkan.

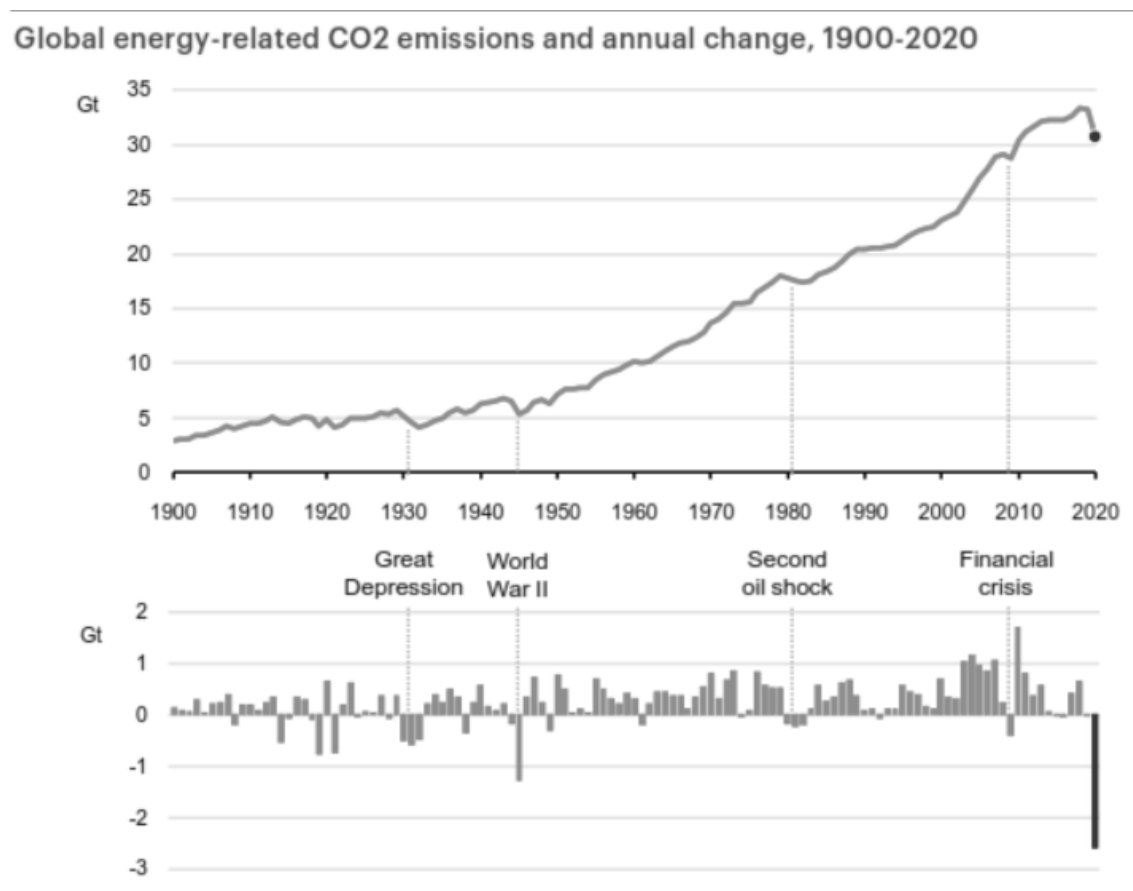

Gambar 9. Pertumbuhan Emisi $\mathrm{CO}_{2}$ Sektor Energi Dunia (IEA,2020)

Pembatasan sosial dan WFH sebagai usaha pengendalian penyebaran Covid-19 disinyalir memberikan manfaat terhadap perbaikan kualitas lingkungan. Khususnya kualitas udara. Perbaikan kualitas udara ini dapat dipengaruhi oleh penurunan pemakaian energi seperti batubara dan minyak bumi serta gas bumi. Kualitas udara membaik karena mendapat kontribusi penurunan emisi CO2 sebesar 3 Gt (gigaton) dari sektor energi terutama industri. Berdasarkan data dari IEA (International Energy Agency) pemakaian energi sektor industri menurun 5\% bila dibandingkan dengan data sebelum pandemi. Pemakaian gas bumi turun sebesar 3\%, salah satunya karena menurunnya pemakaian bahan bakar gas untuk pembangkitan listrik PLTG sebesar $7 \%$. Hal ini dipengaruhi oleh kebijakan lockdown/WFH sehingga beberapa industri non-vital tidak beroperasi. Pemakaian Gas bumi tidak menjadi faktor utama penurunan gas rumah kaca sektor industri Penurunan pemakaian batubara dan minyak bumi masih lebih mendominasi daripada gas bumi yaitu masing-masing sekitar $8 \%$.

Pada masa pandemi dimana permintaan energi untuk pembangkitan listrik dan sektor industri, energi primer gas bumi diharapkan dapat menekan angka bauran energi minyak bumi dan batubara. Namun hal ini harus selaras dengan kinerja hulu gas bumi utamanya pada data cadangan gas bumi. RRR gas bumi pada data terakhir tahun 2017 hanya sebesar 21\%, jauh dari target RUEN sebesar 100\%. Selain itu production to reserve ratio pada tahun 2018-2019 menurun dari 33 tahun menjadi 29 tahun sehingga menandakan cadangan gas bumi yang bisa dimanfaatkan semakin menurun. 


\section{6. $\quad$ Alternatif Pendukung Energi Primer Gas Bumi}

Produk gas sebagai energi primer dapat diperoleh salah satunya dengan gasifikasi. Gasifikasi merupakan proses konversi termal pada biomassa atau batubara menjadi campuran gas dengan tahapan pengeringan, pirolisa, pembakaran, dan reduksi. Gas yang dihasilkan dari gasifikasi ini banyak mengandung $\mathrm{H}_{2}$ dan $\mathrm{CO}$ atau disebut sebagai gas sintesis yang bisa digunakan untuk suplai uap pembangkitan listrik atau sebagai bahan pembentukan senyawa kimia metanol. Salah satu turunan senyawa metanol ini adalah dimetil eter yang dapat dijadikan campuran LPG (Susanto, 2018). RUEN menetapakan target fasilitas pengolahan dimetil eter sebagai produk turunan gasifikasi berproduksi sebesar 1 juta ton untuk campuran LPG pada tahun 2025.

Gasifikasi merupakan proses konversi suatu produk menjadi campuran gas (syngas) seperti hidrogen, karbondioksida, karbonmonoksida, dan gas lainnya yang dapat dibakar atau dijadikan energi kalor dengan menggunakan sedikit udara atau oksigen (Damanhuri, 2010) (Susanto., 2018) (Mukherjee et al., 2020). Sistem gasifikasi terdiri dari tiga proses utama, yaitu gasifier, pembersihan syngas, dan pembangkitan energi (Baharudin et al., 2020.) Pada gasifier terjadi pemanasan substansi organik (sampah) pada temperatur tinggi $\left(500^{\circ} \mathrm{C}-1.800^{\circ} \mathrm{C}\right)$ dengan sedikit oksigen sehingga dihasilkan syngas yang bisa disimpan dan dimanfaatkan (Foster et al., 2020). Syngas terdiri dari $\mathrm{H}_{2}$, $\mathrm{CH}_{4}, \mathrm{CO}, \mathrm{CO}_{2}, \mathrm{H}_{2} \mathrm{O}$, dan $\mathrm{N}_{2}$ yang dapat dimanfaatkan kalornya untuk masuk ke dalam sistem pembangkitan listrik. Gasifier menggunakan agen gasifikasi seperti udara, oksigen, uap. Gasifikasi udara menghasilkan 4-7 MJ/ $\mathrm{Nm}^{3}$ lebih rendah dibandingkan dengan gasifikasi oksigen $10-18 \mathrm{MJ} / \mathrm{Nm}^{3}$ (Bosmans et al., 2013).

Hasil dari proses gasifikasi dapat dimanfaatkan secara langsung maupun tidak langsung. Syngas dapat dimanfaatkan untuk konversi energi termal dan energi listrik. Selain itu syngas dapat dimanfaatkan secara tidak langsung dengan diubah atau diekstrak menjadi gas hidrogen murni, produk metanol dan etanol. Produk metanol dari gasifikasi ini cukup kaya karena bisa diubah menjadi DME (dimetil eter), etilen dan propilen untuk plastik, etanol, dan biodiesel. DME menjadi produk lain gasifikasi batubara yang sangat diunggulkan karena dapat menggantikan LPG serta mendukung pemanfaatan batubara kelas rendah melalui gasifikasi (Susanto,2018).

Gasifikasi batubara akan menjadi teknologi unggulan terutama untuk pemanfaatan batubara dengan kualitas rendah. Batubara dengan kualitas tinggi dapat langsung dimanfaatkan menjadi bahan bakar atau listrik. Gasifikasi batubara dengan kualitas rendah dapat dimanfaatkan menjadi produk metanol seperti DME (Dimetil Eter). Produk DME direncanakan untuk menekan impor LPG berdasarkan RUEN (Rencana Umum Energi Nasional). Fasilitas pengolahan DME sebagai campuran LPG direncanakan terbangun pada tahun 2025 dengan kapasitas 0,4 juta ton. Kebutuhan DME ini dapat dicapai melalui pabrik metanol seperti pada PT Kaltim Metanol Industri. Namun dari 0,6 juta ton kapasitas produksi per tahun, sebanyak 0,4 juta ton dari impor metanol.

Syngas dapat diproduksi secara langsung melalui gas alam. Gas alam yang banyak mengandung metan $\left(\mathrm{CH}_{4}\right)$ disintesis menjadi beberapa syngas $\mathrm{CO}, \mathrm{CO}_{2}$, dan $\mathrm{H}_{2}$ yang membentuk metanol $\left(\mathrm{CH}_{3} \mathrm{OH}\right)$. Syngas metanol ini kemudian dilepaskan dari uap air $\mathrm{H}_{2} \mathrm{O}$ (dehidrasi) sehingga membentuk dimetil eter $\left(\mathrm{C}_{2} \mathrm{H}_{6} \mathrm{O}\right)$ (Puspitasari et al., 2014). Berikut ini pada tabel 3 adalah perbandingan pembentukan produk dimetil eter dari gas alam dan gasifikasi batubara

Pabrik DME di masa akan datang akan menjadi lebih menarik bila dibandingkan dengan fasilitas ekstraksi gas alam skala kecil. Cadangan gas bumi Indonesia sebesar 77,29 triliun kaki kubik (TSCF) pada tahun 2019 (ESDM, 2019). Cadangan gas bumi ini menurun dikarenakan adanya perubahan 
perhitungan klasifikasi cadangan yang mana status cadangan lapangan yang tidak diusahakan menjadi unrecoverable dan contingent serta penurunan besaran cadangan karena adanya perhitungan ulang akibat pengeboran baru atau data penunjang lainnya. Produk DME menjadi salah satu alternatif untuk substitusi LPG di tengah ketidakpastian industri hulu gas bumi. Pembangunan pabrik DME di dekat sumber batubara akan lebih mudah dilaksanakan dibandingkan apabila eksplorasi gas bumi yang hanya skala kecil (Susanto,2018). Berdasarkan perbandingan pada tabel 1 dapat dilihat bahwa untuk kebutuhan unit produksi metanol dari gas alam lebih menguntungkan daripada gasifikasi batubara. Namun gasifikasi batubara yang menghasilkan produk DME ini akan lebih menguntungkan karena jangka waktu cadangan batubara sampai 82 tahun, lebih besar daripada jangka waktu cadangan gas bumi yang hanya 33 tahun berdasarkan RUEN. Hal ini tentu menjadikan substitusi LPG menjadi DME akan lebih diprioritaskan untuk pemenuhan kebutuhan energi nasional.

Tabel 3.

Rangkuman Neraca Massa dan Energi Produksi DME (proses tak langsung, 2000 TPD DME) (Sumber: Susanto,2018)

\begin{tabular}{lcc}
\hline \multicolumn{1}{c}{ Unit Produksi Metanol dari Bahan Baku } & Batubara & Gas Alam \\
\hline Kebutuhan Bahan Baku & 382 TPD & 83,7 MMSCFD \\
Kebutuhan Oksigen, TPD & 2774 & - \\
Kebutuhan make-up BFW, TPD & 2971 & 1128 \\
Kebutuhan Bahan Bakar & 5,3 TPH & 16,3 MMSCFD \\
Kebutuhan steam Bahan Baku & 27,62 & 224 \\
Kebutuhan Listrik, MW & 83,8 & 40,6 \\
Sirkulasi Air Pendingin TPD & 24170 & 19865 \\
Kebutuhan Energi Spesifik, MMBTU/ton metanol & 35,6 & 33 \\
Unit Produksi DME dari Metanol & \multicolumn{2}{c}{ metanol } \\
Kebutuhan Bahan Bakar untuk Sistem Utilitas & Dari heat recovery unit produksi \\
dan steam & \multicolumn{2}{c}{2,5} \\
Kebutuhan Listrik, MW & 2,5 & 4168 \\
Sirkulasi Air Pendingin & 4327 & \multicolumn{2}{c}{} \\
\hline
\end{tabular}

Alternatif lain untuk pendukung energi primer gas bumi adalah coal bed methane (CBM). CBM merupakan gas metana atau gas alam yang dihasilkan dari proses geokimia dan terperangkap pada endapan batubara. Berdasarkan data RUEN menunjukkan bahwa potensi sumber daya CBM di Indonesia sebesar 453 TSCF. CBM termasuk energi baru karena masih berupa prototipe atau belum banyak dikembangkan di Indonesia. Target yang ditetapkan pada RUEN adalah melakukan komersialisasi prototipe menara bor sebanyak 2 unit per tahun. Pengembangan CBM pertama di Indonesia pada tahun 2008 dan sampai sekarang ada 46 kontrak kerja sama pengembangan CBM, walaupun belum ada perkembangan secara signifikan ( $\mathrm{PwC}, 2019$ ). Pengembangan CBM membutuhkan tantangan lebih dikarenakan sulitnya mendapatkan sumber daya gas akibat karakterisitik geologi. Risiko ketidakpastian yang tinggi menyebabkan investasi yang dibutuhkan sangat tinggi. Harga minyak dan gas serta pemanfaatan batubara yang lebih menguntungkan untuk bahan bakar atau pembangkitan listrik menyebabkan investasi CBM tidak menarik. Pembagian risiko investasi perlu ditetapkan mekanismenya (product sharing contract) beserta keringanan pajak untuk akselerasi pengembangan CBM (Acquah-Andoh et al., 2019). 


\section{Kesimpulan}

Peningkatan untuk pencapaian target energi primer gas bumi saling berkaitan antara aktivitas hulu dan hilir. Rantai aktivitas industri gas bumi saling berkaitan, misalkan jika aktivitas eksplorasi minim makan bisa mengakibatkan produksi gas menurun karena sedikitnya cadangan yang bisa dimanfaatkan. Selain itu aktivitas eksplorasi dan produksi gas bumi bisa menurun jika permintaan pada sektor hilir seperti kelistrikkan, industri, transportasi, dan rumah tangga tidak ditingkatkan. Permintaan dan penawaran sangat mempengaruhi Berdasarkan pemanfaatan dan ketersediaan energi primer gas bumi maka didapatkan beberapa poin untuk pemenuhan target RUEN, yaitu:

- Peningkatan aktivitas eksplorasi gas bumi menjadi prioritas pertama untuk peningkatan pencapaian energi primer gas bumi melalui penemuan cadangan gas bumi yang bisa dimanfaatkan. Pembaruan data eksplorasi terkini sangat diperlukan untuk memastikan keberlangsungan aktivitas hulu gas bumi. Kebijakan pemerintah untuk peningkatan partisipasi kegiatan eksplorasi gas bumi diutamakan dalam aktivitas pelelangan sampai kepada tercapai kontrak kerja sama. Dukungan kebijakan pemerintah diperlukan terutama dalam aspek legal dan finansial agar meningkatkan gairah aktivitas eksplorasi gas bumi.

- Perbaikan tata kelola dan hilirisasi gas bumi seperti pemanfaatan gas bumi untuk pasokan petrokimia dan pembangkit listrik serta jaringan gas rumah tangga dan bahan bakar gas (BBG). Hal ini dapat dicapai dengan perbaikan kepastian pasokan gas pada aktivitas hulu gas bumi, insentif biaya investasi, dan optimalisasi supply chain gas bumi untuk harga gas bumi yang kompetitif.

- Penurunan ekspor gas bumi dapat dilakukan salah satunya dengan persiapan pengembangan infrastruktur pemanfaatan gas bumi agar memastikan suplai gas bumi dapat terserap kebutuhan domestik. Salah satu yang dapat meningkatkan serapan kebutuhan domestik adalah industri petrokimia. Sumber gas di lapangan Tangguh dan Abadi dapat terintegrasi dengan petrokimia hulu.

- Koordinasi dengan semua pihak terkait untuk memastikan pemenuhan perizinan terutama izin lingkungan dan isu sosial pengembangan infrastruktur pemanfaatan gas bumi. Salah satu contoh adalah pembangunan LNG South Sulawesi yang ditargetkan pada tahun 2017 namun mengalami kendala terkait perizinan lingkungan dan koordinasi dengan pihak terkait. Pembangunan jaringan gas rumah tangga ini memiliki beberapa kendala terkait kendala perizinan di pusat dan daerah serta isu sosial, Koordinasi dengan pihak terkait seperti pemerintah daerah setempat, kementerian terkait, serta Pertamina dan PGN (PT Perusahaan Gas Negara Tbk) selaku pelaksana pembangunan jaringan gas sangat diperlukan untuk percepatan pembangunan jaringan gas.

- Pengembangan produk DME (Dimetil Eter) sebagai substitusi impor LPG dengan memanfaatkan teknologi gasifikasi batubara. Gasifikasi batubara ini dapat diandalkan untuk memproduksi DME karena jangka waktu cadangan batubara sampai 82 tahun, lebih besar daripada jangka waktu cadangan gas bumi yang hanya 33 tahun berdasarkan RUEN.

- Pada masa pandemi Covid-19 terjadi penurunan konsumsi energi secara global namun gas bumi tidak menjadi faktor dominan yang mendukung penurunan ini. Secara keseluruhan konsumsi gas bumi menurun untuk permintaan kelistrikkan dan bahan baku industri. Namun hal ini berbanding terbalik pada konsumsi gas pada skala rumah tangga yang memiliki peningkatan akibat pengaruh kebijakan WFH (Work From Home). Penurunan 
energi primer lain seperti minyak bumi dan batubara tentunya menjadi kesempatan untuk meningkatkan bauran energi primer gas bumi sehingga mendukung ketercapain persentase $22 \%$ bauran energi. Gas bumi bersama dengan energi terbarukan lainnya dapat menjadi base load dalam kelistrikkan selama masa pandemi ini sehingga meningkatkan persentase pemanfaatan gas bumi. Penurunan harga gas bumi selama masa pandemi juga mengakibatkan penurunan ekspor gas. Hal ini dapat menjadi kesempatan untuk memanfaatkan gas bumi bagi kebutuhan domestik sehingga menunjang ketercapaian kebijakan energi nasional dalam pengurangan ekspor energi dan optimalisasi pemanfaatan dalam negeri.

\section{Daftar Pustaka}

Acquah-Andoh, E., Putra, H. A., Ifelebuegu, A. O., \& Owusu, A. (2019). Coalbed methane development in Indonesia: Design and economic analysis of upstream petroleum fiscal policy. Energy Policy, 131(April), 155-167. https://doi.org/10.1016/j.enpol.2019.04.035

B. H, J. Windarta, and E. Giovanni, "Konversi Limbah Plastik Menjadi Bahan Bakar," Jurnal Energi Baru dan Terbarukan, vol. 1, no. 1, pp. 1-6, Jun. 2020. https://doi.org/10.14710/jebt.2020.8132

Bank Indonesia. 2020. Statistik Keuangan dan Ekonomi Indonesia.

Bappenas. (2019). Rencana Pembangunan Jangka Menengah Nasional 2020-2024.

Bosmans, A., Vanderreydt, I., Geysen, D., \& Helsen, L. (2013). The crucial role of Waste-toEnergy technologies in enhanced landfill mining: A technology review. Journal of Cleaner Production, 55, 10-23. https://doi.org/10.1016/j.jclepro.2012.05.032

BPH Migas. (2020). Perkembangan Infrastruktur Pipa Gas Bumi Nasional Saat Ini.

BPPT. (2020). Outlook Energi Indonesia 2020:Dampak Pandemi Covid-19 terhadapSektor Energi di Indonesia. Jakarta:BPPT.

ENGVA. (2002). Modul Kendaraan Berbahan Bakar Gas. Jerman: GTZ.

Enri Damanhuri. (2010). Pengelolaan Sampah Tepadu.

ESDM. (2018). Neraca Gas Bumi Indonesia.

ESDM. (2018). Laporan Tahunan Capaian dan Program Kegiatan 2018:Pemanfaatan Gas Bumi untuk Energi Berkeadilan.

ESDM. (2019). Laporan Tahunan Capaian dan Program Kegiatan 2019:Perizinan online.

ESDM. (2020). Statistik Ketenagalistrikkan Tahun 2019. Jakarta: Setjen Ketenagalistrikkan.

ESDM, K. (2018). Neraca Gas Bumi Indonesia.

Foster, W., Azimov, U., Gauthier-Maradei, P., Molano, L. C., Combrinck, M., Munoz, J., Esteves, J. J., \& Patino, L. (2021). Waste-to-energy conversion technologies in the UK: Processes and barriers A review. Renewable and Sustainable Energy Reviews, 135(August 2020). https://doi.org/10.1016/j.rser.2020.110226

Hartono, D., Hastuti, S. H., Balya, A. A., \& Pramono, W. (2020). Modern energy consumption in Indonesia: Assessment for accessibility and affordability. Energy for Sustainable Development, 57, 5768. https://doi.org/10.1016/j.esd.2020.05.002

International Energy Agency. (2020). Global Energy Review 2020.

Mukherjee, C., Denney, J., Mbonimpa, E. G., Slagley, J., \& Bhowmik, R. (2020). A review on municipal solid waste-to-energy trends in the USA. Renewable and Sustainable Energy Reviews, 119(March 2019). https://doi.org/10.1016/j.rser.2019.109512 
Vol. 2, No. 1, pp $36-52$

doi: $10.14710 /$ jebt.2021.10049

Paramitra, Rastri. (2018). Gas Bumi Indonesia: Stimulus Ekonomi Vs Komoditi Dampak Fluktuasi dan Deviasi Harga Minyak Mentah Indonesia Terhadap APBN 2018 dan Perekonomian Indonesia. Buletin APBN, III(April).

PwC. (2019). Oil and Gas in Indonesia. Taxation Guide.

Santika, W. G., Urmee, T., Simsek, Y., Bahri, P. A., \& Anisuzzaman, M. (2020). An assessment of energy policy impacts on achieving Sustainable Development Goal 7 in Indonesia. Energy for Sustainable Development, 59, 33-48. https://doi.org/10.1016/j.esd.2020.08.011

Shell. (2018). Sky:Mencapai tujuan paris agreement.

Susanto,Herri. (2018). Orasi Ilmiah Guru Besar Institut Teknologi Bandung. Forum Guru Besar Institut Teknologi Bandung

Tim Sekretaris Jenderal Dewan Energi Nasional. (2019). Indonesia Energy Out Look 2019. Journal of Chemical Information and Modeling, 53(9), 1689-1699.

Tim Sekretaris Jenderal Dewan Energi Nasional. (2019). Indonesia Energy Out Look 2019. Jakarta:DEN.

Tim Sekretaris Jenderal Dewan Energi Nasional. (2020). Bauran Energi Nasional 2020. Jakarta:DEN.

Triyatno, J. (2018). Perbandingan Penggunaan Gas Alam Terhadap Lpg Dalam Memenuhi Kebutuhan Rumah Tangga Di Bontang. Al Ulum Sains Dan Teknologi, 4(1), 14-20.

W.W.Purwanto et al. Status and Outlook of Natural Gas Industry Development in Indonesia. Journal of Natural Gas Science and Engineering. 29 (2016), 55-65.

Widyastuti, N. L., \& Nugroho, H. (2020). Dampak Covid-19 terhadap Industri Minyak dan Gas Bumi: Rekomendasi Kebijakan untuk Indonesia. Jurnal Perencanaan Pembangunan: The Indonesian Journal of Development Planning, 4(2), 166-176. https://doi.org/10.36574/jpp.v4i2.116

Winarsih Gede; Setiawati, Eviana Dewi; Yudiputri, Ajeng Puspitasari, W. W. (2014). Pra Desain Pabrik Dimethyl Ether (Dme) Dari Gas Alam. Jurnal Teknik ITS, 3(Vol 3, No 2 (2014)), B216-B219. http://ejurnal.its.ac.id/index.php/teknik/article/view/8344 